Ks. Stanislaw Piech

\title{
KSIĘDZA JANA SALAMUCHY MSZA ŻYCIA
}

$\mathrm{Na}$ tle walczącej Warszawy, w sierpniu 1944 r. niezapomniana pozostala bohaterska postawa ks. Jana Salamuchy, filozofa, profesora Uniwersytetu Jagiellońskiege, przypieczętowana ofiarą własnego życia. Narodowa pamięć wielkiej daniny życia i krwi w powstaniu warszawskim, która odżyla w pięćdziesiątą rocznicę tego heroicznego zrywu wolnościowego, skłania do przypomnienia żywota tego niezwykłego kapłana.

Ks. Jan Salamucha urodził się 10 czerwca 1903 r. w Warszawie, w glęboko religijnej rodzinie robotniczej Andrzeja i Stanisławy z Marciniaków. Rodzice mieszkali niedaleko kościoła Św. Augustyna, gdzie jako chłopiec służył do Mszy św. W posłudze ołtarza zrodziło się zapewne u niego pragnienie całkowitego poświęcenia swego życia w służbie Bogu i czlowiekowi w Chrystusie. W gimnazjum wyróżnial się swymi zdolnościami, szczególnie zaś zacięciem w dyskusjach, w których niejednokrotnie podejmowal trudne problemy religijno-moralne, zwłaszcza w czasie katechezy.

\section{WYBRAL KAPŁAŃSTWO}

Po ukończeniu sześciu klas gimnazjum humanistycznego wstąpił w 1919 r. do Seminarium Duchownego w Warszawie, w którym nauka były wówczas tak zorganizowana, że właściwe studia teologiczne poprzedzal dwuletni kurs humanistyczno-filozoficzny. Kurs ten stanowił wstęp do waściwego studium teologii. Alumni zaś na podstawie specjalnego zezwolenia Ministerstwa Wyznań Religijnych i Oświecenia Publicznego (WRiOP) byli immatrykulowani jako studenci zwyczajni Wydziału Teologicznego Uniwersytetu Warszawskiego, na którym mogli uzyskiwać stopnie 
akademickie. W sierpniu 1920 r., gdy wojska sowieckie zagrażające niepodległości odrodzonej ojczyzny, stanęły na przedpolach stolicy, ogarnięty patriotycznym żarem, wraz $z$ innymi klerykami zgłosił się jako ochotnik do wojska i przez trzy miesiące był sanitariuszem. Po złożeniu w roku akademickim 1923/24 wszystkich egzaminów obowiązujących w Seminarium Duchownym studiowal w Sekcji Filozoficznej na Wydziale Teologii Katolickiej Uniwersytetu Warszawskiego. W tym samym czasie na Wydziale Filozoficznym studiował filozofię, logistykę i matematykę. Był uczniem Stanisława Leśniewskiego, Jana Lukasiewicza i Władysława Tatarkiewicza. Słuchał także wykładów z embriologii porównawczej Jana Tura. Na Wydziale Lekarskim uczęszczał na wykłady i ćwiczenia Franciszka Czubalskiego z fizjologii czlowieka. Kierownik Sekcji Filozoficznej na Wydziale Teologii Katolickiej, ks. Stanisław Kobyłecki, wymagał bowiem od swych uczniów, aby słuchali także wykładów logiki matematycznej, matematyki a nawet przyrody ${ }^{1}$.

W dniu 21 lutego 1926 r. ks. Salamucha otrzymal święcenia kaplańskie, których tylko jemu samemu udzielił biskup polowy Wojska Polskiego Stanisław Gall, w swej kaplicy domowej ${ }^{2}$. Stanął przy ołtarzu, by sprawować Najśw. Ofiarę. Razem z Chrystusem oddawał Bogu samego siebie na wierną służbę kapłańską. Msza św. sprawowana na ołtarzu przedłużała się w jego mszę życia, odprawianą każdego dnia w podejmowanym wciąż na nowo trudzie realizowania posłannictwa kapłańskiego, przyjętego na siebie w chwili święceń. Ta msza życia urzeczywistniała i aktualizowała się w jego dalszych studiach przygotowujących go do działalności naukowej, następnie w nauczaniu na katedrze profesorskiej i w pracy badawczej, osiągając swój szczyt w męczeńskich dniach walczącej Warszawy w sierpniu 1944 r.

\section{KU KATEDRZE UNIWERSYTECKIEJ}

W dniu 24 października 1927 r. ks. Salamucha został na Wydziale Teologii Katolickiej Uniwersytetu Warszawskiego promowany na doktora filozofii chrześcijańskiej na podstawie rozprawy Teoria wynikania modalnego Arystotelesa. Promotorem byl wspomniany ks. S. Kobylecki. W tym

${ }^{1}$ L. Koj, Uwagi o życiu ks. Jana Salamuchy. „Summarium” 18 (1989), s. 10-151; K. Michalski, Ks. Jan Salamucha. „Przegląd Filozoficzny” 42 (1939-1946), s. 338; S. Piech, Salamucha Jan. W: Polski Slownik Biograficzny. T. 34, s. 354.

${ }^{2}$ "Wiadomości Archidiecezjalne Warszawskie” 16 (1926), s. 128 odnotowały taką datę jego święceń. Natomiast „Elenchus cleri saecularis ac regularis archidioecesis varsaviensis" we wszystkich swoich rocznikach podawal rok 1925. Ks. J. Salamucha nie mógł być jednak święcony razem ze swoim kursem w 1925 r., ponieważ nie miał jeszcze odpowiedniego wieku wymaganego przez prawo kanoniczne. 
samym roku wyjechał na dalsze studia filozoficzne do Rzymu, gdzie w 1929 r. uzyskał na Uniwersytecie Gregoriańskim tytuł magister aggregatus za rozprawę $D e$ deductione apud Aristotelem et $S$. Thomam. Po powrocie z zagranicy krótko był wikariuszem parafialnym w Wiązownej. W okresie od 1 października 1929 r. do 31 sierpnia 1933 r. wykladal filozofię w Metropolitalnym Seminarium Duchownym w Warszawie. W celu lepszego zrozumienia wykładanych zagadnień posługiwał się językiem polskim zamiast łaciny, będącej wówczas w powszechnym użyciu w zakładach teologicznych. Uczył także w Małym Seminarium. Marzył o pracy dydaktyczno-naukowej na uniwersytecie. Chciał uzyskać veniam legendi na Wydziale Teologicznym Uniwersytetu Jagiellońskiego (UJ), gdzie wykładał europejskiej sławy ks. Konstanty Michalski CM, chluba nauki polskiej okresu międzywojennego. Zainteresowania naukowe ks. Salamuchy zwrócily bowiem na niego uwage tego wybitnego Profesora, który swoim autorytetem wyjednal mu u metropolity warszawskiego kard. A. Kakowskiego zezwolenie na habilitację w UJ. Po przeprowadzeniu przewodu habilitacyjnego Rada Wydziału Teologicznego UJ w dniu 2 czerwca 1933 r. przyznała ks- Salamusze veniam legendi w zakresie filozofii chrześcijańskiej na postawie rozprawy Pojęcie dedukcji u Arystotelesa $i$ św. Tomasza z Akwinu. Rada Wydziału Teologicznego UJ, dostosowując się do wymagań konstytucji apostolskiej Deus scientiarum Dominus (1931) papieża Piusa XI w zakresie rozszerzenia i pogłębienia studiów filozoficznych, uchwaliła na posiedzeniu w dniu 8 czerwca 1933 r., w porozumieniu z Ministerstwem WRiOP, utworzenie drugiej katedry filozofii chrześcijańskiej od początku roku akademickiego 1933/34. Na zastępcę profesora zaproponowano ks. Salamuchę, który przyjąwszy zaproszenie Wydziału zrezygnował $\mathrm{z}$ wykładów $\mathrm{w}$ seminarium warszawskim. Ministerstwo WRiOP w dniu 25 września 1933 r. utworzyło tę katedrę, ale niestety nie zatwierdziło habilitacji ks. Salamuchy ani jego zastępstwa na nowo powstałej katedrze, $\mathrm{z}$ powodu podnoszonych przeciw niemu zarzutów, że nie posiadal świadectwa maturalnego oraz przedstawił pracę, na podstawie której uzyskal stopień naukowy w Rzymie. W tych warunkach Wydział uchwalił powierzenie mu w roku akademickim 1933/34 wykładów zleconych w wymiarze 5 godz. tygodniowo. O zajęcia te, obok Wydziału, zabiegał także abp Adam Sapieha. Ministerstwo wyraziło zgodę ${ }^{3}$. Ks. Salamucha jednak $\mathrm{z}$ powodu odrzucenia habilitacji nie przyjąl tej oferty. „Po zapoznaniu się z przebiegiem mojego przewodu habilitacyjnego - napisal do Rady Wydziału Teologicznego UJ w dniu 15 grudnia 1933 r. - nie

${ }^{3}$ A. Usowicz, Listy Jana Lukasiewicza do ks. Konstantego Michalskiego. "Analecta Cracoviensia" 2 (1970), s. 126-127; A. Usowicz, K. Kłósak, Ksiądz Konstanty Michalski (1879-1947). Kraków 1949, s. 38-39; S. Piech, dz. cyt., s. 354-355. 
czuję się na siłach do tego, żeby nadal brać udział w oficjalnym życiu naukowym, $\mathrm{z}$ tego względu ofiarowanych mi łaskawie wykładów zleconych objąć nie moge" "4. Wrócil do swojej diecezji. Stanowisko wykładowcy filozofii w seminarium było już zajęte przez ks. Józefa Pastuszkę, późniejszego profesora Katolickiego Uniwersytetu Lubelskiego. Przeszedł więc do pracy duszpasterskiej jako wikariusz parafii Matki Boskiej Loretańskiej w Warszawie. Wydawało się, że jego marzenia o katedrze uniwersyteckiej zostały już calkowicie pogrzebane. Nie wrócił nawet na swoje dawne stanowisko wykładowcy w Seminarium Duchownym. Przyszło mu znieść niejedną przykrość z tego powodu. Cierpienie to jednak nie trwało długo. $\mathrm{Na}$ początku roku akademickiego $1934 / 35$ został z powrotem powołany na wykładowcę filozofii w warszawskim Seminarium Duchownym. W Krakowie natomiast ks. Michalski nie ustawal w staraniach o zatwierdzenie jego habilitacji i zatrudnienie go w UJ. Pod wpływem Profesora ks. Salamucha przyjął w listopadzie 1934 r. wspomniane wyklady w UJ. Przybył ponownie do Krakowa i zamieszkał w Częstochowskim Seminarium Duchownym przy ul. Bernardyńskiej 3.

\section{NA KATEDRZE FILOZOFII CHRZEŚCIJAŃSKIEJ}

Ks. Salamucha zajęcia dydaktyczne w UJ rozpoczął 1 grudnia 1934 r. Rada Wydziału Teologicznego UJ zwróciła się w 1936 r. do Ministerstwa WRiOP z prośbą o ponowne rozpatrzenie sprawy habilitacji ks. Salamuchy, podkreślając, że uznaje go ,za jedynego obecnie w Polsce przedstawiciela logiki matematycznej wśród duchowieństwa i nie chce się w żaden sposób pozbyć jego współpracy, powolując się na kompetentny sąd twórcy $\mathrm{i}$ najwybitniejszego reprezentanta logistyki w Polsce, prof. Jana Łukasiewicza"s. Habilitacja została zatwierdzona dnia 17 listopada 1936 r., ale już od początku roku akademickiego 1936/37 ks. Salamucha był zastępcą profesora w II Katedrze Filozofii Chrześcijańskiej w UJ.

We Wszechnicy Jagiellońskiej ks. Salamucha wykładał logikę, krytykę poznania, kosmologię, teodyceę i historię filozofii starożytnej. W latach 1934/35-1935/36 prowadził ćwiczenia proseminaryjne z logiki i epistemologii dla studentów pierwszego kursu. Czytano i objaśniano Analityki drugie Arystotelesa wraz z komentarzem św. Tomasza z Akwinu. W następnych dwóch latach czytał $\mathrm{i}$ komentował tekst klasycznej logiki scholastycznej

\footnotetext{
4 Archiwum Uniwersytetu Jagiellońskiego (AUJ), S II 619, Ks. Jan Salamucha do Rady Wydzialu Teologicznego UJ, Warszawa, 15 XII $1933 \mathrm{r}$.

5 AUJ, S II 619, Dziekan wydzialu Teologicznego UJ (ks. K. Michalski) do Ministerstwa WRiOP, Kraków $20 \times 1936 r$.
} 
Jana od św. Tomasza OP Ars logica i prowadził ćwiczenia rachunkowe z logiki formalnej. W roku akademickim 1936/37 otworzył seminarium z historii logiki, na którym analizowal wybrane teksty Summy contra gentiles św. Tomasza z Akwinu ${ }^{6}$. Ks. Salamucha stosował ,nowe narzędzia logiczne $w$ wykładach $z$ filozofii, uwydatniając ciągle ścisłe związki pomiędzy dowodzonymi tezami a obranymi na czele aksjomatami i zalożeniami. To przykuwało uwagę młodzieży, to - i umiejętność wydobywania z nauki i życia ludzkiego najistotniejszych zagadnień" - wspomniał go ks. Michalski?

Ks. Salamucha bral czynny udział w ruchu naukowym. W 1934 r. wraz z o. Józefem M. Bocheńskim OP i Bolesławem Sobocińskim zalożyli Koło Krakowskie na wzór Koła Wiedeńskiego, które najwcześniej zaczęło szeroko stosować logistykę we filozofii. Koło Krakowskie było szkołą filozoficzną pozostającą pod wplywem J. Lukasiewicza. „Najważniejszym myślicielem grupy - zdaniem o. J. M. Bocheńskiego - był ks. Salamucha, o ile idzie o jego oryginalność myśli i jakość wykonanej pracy" 8 . Oryginalność ta polegała przede wszystkim na zastosowaniu logiki matematycznej. Ks. Salamucha przeciwstawiał się poglądom Koła Wiedeńskiego, według którego logicznym następstwem nowych metod miałaby być postawa pozytywistyczna, przeciwstawiająca się wszelkiej metafizyce. Filozoficzna szkoła lwowsko-warszawska, do której należy zaliczyć także neotomistę ks. Salamuchę, osiągnęla w latach trzydziestych bieżącego stulecia sławę międzynarodową, głównie dzięki logice ${ }^{9}$.

W 1938 r. Rada Wydziału Teologicznego UJ wszczęła postępowanie mające na celu wystąpienie do Ministerstwa $\mathrm{z}$ wnioskiem o zamianowanie ks. Salamuchy profesorem nadzwyczajnym II Katedry Filozofii Chrześcijańskiej. „Powołanie ks. dra Jana Salamuchy na katedrę filozofii chrześcijańskiej przyniesie nie tylko pożytek Wydziałowi Teologicznemu - napisal uspomniany już Lukasiewicz, referując jego dorobek - ale przyczyni się uydatnie $\mathrm{i}$ do podniesienia studium filozofii w Uniwersytecie Jagiellońskim" 10. Dziekan Wydziału, ks. Władysław Wicher zwrócił się, wedle

- Spisy wykladów Uniwersytetu Jagiellońskiego z lat 1935/36-1938/39; AUJ WT 67 Spramodzanie z dzialalności seminarium przy II Katedrze Filozofii Chrześcijañskiej z lat 193637-1937/38; Ks. J. Salamucha do Dziekanatu Wydziału Teologicznego UJ, Kraków 15 II 1938: W Bibliotece Jagiellońskiej w Krakowie zachowały się powielane skrypty z wykładów ks. J. Salamuchy: Krytyka poznania. Kraków 1935, s. 47; Logika. Kraków 1935, s. 57.

' K. Michalski, Ks. Jan Salamucha. W: 70 żywotów. Wybór i red. A. Paluchowski. Kraków 1977, s. 211.

- J. Bocheński, Wspomnienia. Kraków 1993, s. 123.

- J. Woleński, Filozoficzna szkola lwowsko-warszawska. Warszawa 1985, s. 23-26; Miedzy logikq a wiarq. Z Józefem M. Bocheńskim rozmawia J. Parys. Montricher 1988, s. 18-20, 138.

10 Archiwum Akt Nowych w Warszawie, MWWiOP 5512, Referat J. Lukasiewicza. Warszawa 3 V 1938. 
obowiązującego wówczas ustawodawstwa uniwersyteckiego, do wszystkich profesorów filozofii chrześcijańskiej w uniwersytetach państwowych oraz do wszystkich profesorów filozofii na wydziałach filozoficznych i humanistycznych tych uczelni z prośbą o przedstawienie odpowiedniego kandydata. W ankiecie wzięli udział wszyscy profesorowie $\mathrm{i}$ - co warto podkreślić - na 14 odpowiedzi było 10 głosów stawiających ks. Salamuchę albo jako jedynego kandydata, albo na pierwszym miejscu ${ }^{11}$. Dnia 6 grudnia $1938 \mathrm{r}$. prezydent Rzeczypospolitej, Ignacy Mościcki, mianował go profesorem nadzwyczajnym z ważnością prawną do 1 stycznia 1939 r. ${ }^{12}$

Maksymalista, wiele wymagający od siebie, był równocześnie czlowiekiem pogodnym i wesolym $z$ dużym poczuciem humoru. Odznaczał się postawą żołnierską, przebojową. Odważny w wyglaszaniu swoich poglądów był nieustępliwy w dyskusjach, dopóki nie przedstawiono mu przekonywających argumentów. Wymagający duszpasterz, otwarty na dialog z drugim czlowiekiem, był kapłanem wielkiej prostoty i pokory, bardzo uczynny i ofiarny, który mimo głębi swojej wiedzy, przyciągał do siebie urokiem swojej osobowości. Żywo interesował się problemami mlodzieży akademickiej. Był też przez nią szczególnie lubiany. Kochał literaturę i muzykę klasyczną. Uprawiał wspinaczkę wysokogórską i pływał kajakiem $^{13}$.

\section{W PRACY BADAWCZEJ}

Zainteresowania naukowe ks. Salamuchy skupiały się głównie wokół historii filozofii starożytnej i średniowiecznej, ze szczególnym uwzględnieniem logiki. W badaniach historycznych stosował ścisłe metody logiki matematycznej. Znajomość paleografii umożliwiała mu przeprowadzenie analizy logicznej średniowiecznych rękopisów w bibliotekach Krakowa, Paryża i Watykanu. W rozprawie Pojęcie dedukcji u Arystotelesa $i$ św. Tomasza (Warszawa 1930) ks. Salamucha wykazal sprzeczności w arystotelesowskiej teorii dedukcji, spowodowane, jego zdaniem, przyjęciem przez Arystotelesa za podstawę swych badań trzech typów ówczesnego myślenia naukowego: rozumowania matematycznego, przyrodniczego i sylogizmu kategorycznego oraz niewłaściwego ich uogólnienia ${ }^{14}$. Pod wpły-

11 Tamże, Dziekan Wydzialu Teologicznego UJ do Ministerstwa WRiOP. Kraków 7 V 1938.

12 AUJ, S II 619, Prezydent Rzeczypospolitej do ks. J. Salamuchy, Warszawa 6 XII 1938.

${ }^{13}$ K. Zgorzelska, Ksiq̨dz Jan Salamucha. „Więż 7 (1965), nr 11, s. 73-75; L. Koj, dz. cyt., s. 155 .

${ }^{14}$ T. Czeżowski, Salamucha Jan. W: Filozofia w Polsce. Wrocław 1971, s. 342; K. Michalski, Ks. Jan Salamucha. „Przegląd Filozoliczny” 42 (1939-1946), s. 339. 
wem J. Lukasiewicza zajął się logiką zdań u Wilhelma Ockhama. W tekście Summae totius logicae Ockhama rozróżnil implikację materialną i formalną. Wykazał, że Venerabilis Inceptor był najwybitniejszym średniowiecznym znawcą logiki zdań. Znał 27 tez rachunku zdań. Dokonał tego w artykule Logika zdań $u$ Wihlema Ockhama ${ }^{15}$. Wyjaśnił źródła traktaciku o tzw. insolubiliach (nierozwiązalnikach) w średniowiecznych podręcznikach logiki. Dowiódł autentyczności tego traktatu w Sumie logicznej Ockhama. Problematyką tą zajął się w pracy Pojawienie się zagadnień antynomialnych na gruncie logiki średniowiecznej ${ }^{16}$. W rozprawie Dowód ex motu na istnienie Boga. Analiza logiczna argumentacji św. Tomasza $z$ Akwinu sformalizowal dowód na istnienie Boga z Summy contra gentiles i wykazal, że rozumowanie św. Tomasza wykroczyło poza ramy logiki Arystotelesa ${ }^{17}$. Była to pierwsza matematyczno-logiczna analiza dowodu istnienia Boga ${ }^{18}$.

Drugi kierunek zainteresowań naukowych ks. Salamuchy wiódł go w dziedzinę filozofii systematycznej. Dążył do tego, aby współczesna scholastyka była maksymalistyczna w zasięgu i metodzie w celu przeciwstawienia się noepozytywizmowi wiedeńskiemu. W artykule Wspólczesna neoscholastyka wloska wiele uwagi poświęcił relacji neoscholastyki do neopozytywizmu ${ }^{19}$. W rozprawce Zestawienie scholastycznych narzędzi logicznych $z$ narzędziami logistycznymi domagal się zasymilowania przez filozofię neoscholastyczną osiągnięć logiki matematycznej, jeśli nie chce zerwać $\mathrm{z}$ wielowiekową tradycją stosowania maksymalnie ścisłych narzędzi myślowych ${ }^{20}$. Zagadnieniu inwencji w twórczości logicznej poświęcił opracowanie $O$ „mechanizacji" myślenia ${ }^{21}$. Sprawą pojęć analogicznych zajął się w artykule $O$ możliwosiciach ścislego formalizowania dziedziny pojęc analogicznych ${ }^{22}$. Ks. Salamucha zabiegal o stosowanie we współczesnej scholastyce ścislych metod logiki matematycznej przy równoczesnym śmiałym podejmowaniu wszelkich zagadnień metafizycznych. Prace jego odznaczały się jasnym ujęciem zagadnień, ścisłością rozumowania i szerokim horyzontem metafizycznym ${ }^{23}$.

15 "Przegląd Filozoficzny" 30 (1935), s. 210-223.

16 Tamże, 40 (1937), s. 68-89, 320-343.

17 "Collectanea Theologica” 15 (1934), s. 53-92.

1s J. Bocheński, J. Drewnowski, J. Salamucha, Rola logistyki w filozofii chrześcijańskiej. Warszwa 1936, s. 4; J. Bocheński, Wspomnienia, s. 126.

19 "Przegląd Filozoliczny" 39 (1936), s. 84-89.

20 Tamże, s. $35-48$.

${ }^{21}$ Myśl katolicka wobec logiki wspólczesnej. W: „Studia Gnesnensia” XV. Poznań 1937, s. $112-121$.

22 Tamże, s. 122-153.

${ }^{23}$ K. Michalski, Ks. Jan Salamucha. „Przegląd Filozoficzny” 42 (1939-1946), s. 341; Z. Wolak, Neotomizm a szkola lwowsko-warszawska. Kraków 1993, s. 88-95; Tenże, Próba 
Myśl ks. Salamuchy obejmowała szeroki widnokrąg bogatej problematyki światopoglądu chrześcijańskiego. $Z$ pasją podejmowal zagadnienia moralne i społeczne. Osiągnięcia J. Lindworsky'ego TJ w zakresie psychologii skłoniły go do zajęcia się problematyką moralną wolności woli ${ }^{24}$. W oparciu o dorobek wspólczesnej sobie psychologii, a szczególnie wspomniane wyżej badania Lindworsky'ego dokonał próby nowego spojrzenia na motywacyjną rolę wartości w procesie kształcenia charakteru ${ }^{25}$. W artykule Wzgledność $i$ bezwzgledność etyki katolickiej zarysowal „teoretyczną konstrukcję moralności katolickiej” ${ }^{26}$. W pracy Zagadnienie przymusu $w$ życiu spolecznym dał oryginalną próbę zastosowania w etyce katolickiej osiągnięć współczesnej logiki ${ }^{27}$. Wygłaszał także prelekcje na kursach filozofii chrześcijańskiej organizowanych przez Akcję Katolicką dekanatu krakowskiego (1935/36) i Naukowy Instytut Katolicki (1938/39). Od roku 1936/37 kierował Sekcją Zagadnień Filozoficzno-Religijnych Stowarzyszenia Katolickiej Młodzieży Akademickiej "Odrodzenie" 28 .

\section{OFIARA ŻYCIA}

Niezwykle pracowity „nie szczędził siebie, rozdawał się szczodrze, zwłaszcza kiedy niebezpieczeństwo zagrozilo samemu istnieniu narodu" ${ }^{29}$. We wrześniu 1939 r. ks. Salamucha wyjechał do Warszawy, gdzie walczył w obronie stolicy jako kapelan (ochotnik) zalogi fortu Bema na Czystem. Tam odznaczono go Krzyżem Walecznych. Po powrocie do Krakowa został 6 listopada 1939 r. aresztowany wraz z profesorami i asystentami UJ w oslawionej ,Sonderaktion Krakau”. Przeszedł przez więzienia w Krakowie (Montelupich) i Wrocławiu, obozy koncentracyjne w Sachsenhausen (od 28 listopada tego roku) i Dachau (od 14 grudnia 1940 r.). Zwolniony z obozu 4 stycznia 1941 r., zmizerowany i obrzękly, wrócił do Krakowa. Stąd po krótkiej kuracji już na wiosnę tego samego roku wyjechał do Warszawy, gdzie zostal wikariuszem parafii św. Jakuba na Ochocie i kierował „Caritasem". Wykładał fïlozofię i prowadził semina-

reformy tomizmu przez ks. J. Salamuche. „Tarnowskie Studia Teologiczne” 13 (1994), s. $115-128$.

24 Rola woli w naszym życiu psychofizycznym. „Glos Kapłański” 6 (1932), s. 7-15.

2s Uwagi na temat ksżtalcenia charakteru. „Miesięcznik Katechetyczny i Wychowawczy" 22 (1933), s. 6-28.

26 „Przegląd Powszechny” 53 (1936). T. 209, s. 36-51.

27 Zagadnienie przymusu w życiu spolecznym. „Prąd” 26 (1939). T. 37, s. 172-183.

${ }^{28}$ S. Piech, dz. cyt., s. 355.

${ }^{29}$ K. Michalski, Ks. Jan Salamucha. „Przegląd Filozoliczny” 42 (1939-1946), s. 341. 
rium logistyczne dla kleryków Metropolitalnego Seminarium Duchownego, oraz logikę matematyczną i metafizykę na Wydziale Humanistycznym tajnego Uniwersytetu Ziem Zachodnich w Warszawie (bylym Uniwersytecie Poznańskim). Wygłaszał liczne kazania, konferencje i odczyty cieszące się dużym zainteresowaniem inteligencji skupionej w ,Juventus Christiana". Był bowiem utalentowanym mówcą. Jego niedzielne konferencje w kościele Św. Jakuba przyciągały nie tylko praktykujących katolików, ale także zobojętniałych w wierze. Ks. Salamucha należal do kręgu prof. Władyslawa Tatarkiewicza, u którego na poniedziałkowych zebraniach dyskutowano nad zagadnieniami filozoficznymi. Przygotowywał do druku książkę $O$ chrześcijańskim stylu w filozofii, zawierającą w znacznej części prelekcje wygłaszane na wspomnianym kursie zorganizowanym przez Naczelny Instytut Katolicki. Praca ta nie zostala jednak opublikowana. Zachowane jej fragmenty drukowal po wojnie ,Tygodnik Powszechny” (R. 2:1946, nr 2-7), „Dziś i Jutro” (R. 2:1946, nr 17, s. 19-20); R. 3:1947, nr 30), „Znak" (R. 2:1947, s. 481-499). Pisywal do prasy podziemnej (tygodnik „Walka” 1942, nr 49).

W sierpniu $194 \overline{4}$ r., gdy stolica poderwała się do walki o wolność, msza życia ks. Salamuchy zaczęła się zbliżać do swego najważniejszego momentu. Calkowicie zaangażowany w swoje posłannictwo kapłańskie często służył wiernym posługą sakramentu pokuty. Pocieszal i umacnial cierpiących. Dojrzewał do złożenia ofiary swego życia na ołtarzu Chrystusa. W powstaniu warszawskim walczyl pod pseudonimem ,Jan”. Byl kapelanem-wicedziekanem dekanatu Północ Okręgu Warszawskiego Armii Krajowej. Jako dziekan IV Obwodu Ochota zorganizowal tam służbę kapelańską spośród księży parafii Św. Jakuba i mieszkających w pobliżu księży orionistów. Należał do obrońców „Reduty Wawelskiej" na Ochocie. Był także kapelanem tamtejszego szpitala powstańczego ${ }^{30}$. „Podtrzymywal [...] słabych i wątpiących, zarażal u'szystkich swoją pogodą, rozpalał żarliwym patriotyzmem" ${ }^{31}$. Gdy po 10 dniach ciężkich walk powstańcy zostali przez Niemców zmuszeni do wycofania się z zajmowanych stanowisk bojowych, ks. Salamucha pozostał z rannymi i ludnością cywilną. Namawiany do wyjścia kanałami odmówil, twierdząc że jest za wysoki i w nich się nie zmieści. Był, co prauda, wysoki i barczysty, ale prawdziwym jednak powodem odmowy byla wola pomocy rannym, których nie chcial pozostawić samych. Zginął 11 sierpnia 1944 r. osłaniając sobą bezbronnych, zastrzelony przy ul. Wawelskiej 60 przez żołnierzy brygady SS RONA (Russkaja

30 S. Piech, dz. cyt., s. 355-356.

31 J. Wroniszewski, Ochota 1944. Warszawa 1970, s. 74-75. 
Osvoboditielnaja Narodnaja Armia), pod dowództwem gen. Mieczysława Kamińskiego ${ }^{32}$.

Skończyła się msza życia ks. Jana Salamuchy. W pełni sił twórczych, w wieku 41 lat, zbrodnicza ręka przerwała nić jego żywota. Zgasła wschodząca gwiazda logistyki polskiej. Pozostały pamięć jego ofiary i utrwalone w pismach przemyślenia naukowe.

32 W. Bartoszewski, Dni walczacej stolicy. Warszawa 1989, s. 63; S. Piech, dz. cyt., s. 356; J. Wroniszewski, Ochota 1939-1945. Warszawa 1976, s. 686; M. Wiśniewska, M. Sikorska, Szpitale powstańczej Warszawy. Warszawa 1991, s. 31; K. Zgorzelska, dz. cyt., s 71. 